\title{
STUDIES ON THE EFFECT OF MILL MICROSTRUCTURE UPON TOOL LIFE DURING SLOT MILLING OF TI6AI4V ALLOY PARTS
}

\section{BADANIA WPŁYWU MIKROSTRUKTURY FREZU NA TRWAŁOŚĆ OSTRZA W PROCESIE FREZOWANIA ROWKÓW W STOPIE TYTANU TI6AI4V*}

\begin{abstract}
Different forms of tool wear occur in the milling process. Mechanical wear, which has a range of varieties, is a typical form of wear connected with mill operating. One of the varieties of mechanical wear, frequently occurring during milling machiningresistant materials, is undesirable catastrophic wear. Avoiding that kind of wear by appropriate selection of technological parameters, sort of burning carbides and their microstructure constitutes basic information about reliability of the tool. This paper presents the findings from the experimental testing of the impact SC grain size in end mills on the cutting tool tooth (bit) service life and surface topography after slot milling Ti6Al4V alloy parts. The tool wear indicator was determined in compliance with PN-ISO 8688:1996. It was demonstrated that ultra fine grain SC milling cutters are the most resistant to chipping, whereas the surfaces machined with these cutting tools reveals the lowest roughness. The coarse grain SC milling cutters are among those with the shortest service life of all tested tools.
\end{abstract}

Keywords: titanium alloys, milling, wear, roughness.

\begin{abstract}
W procesie skrawania występuja różne formy zużycia narzędzi. Zużycie mechaniczne, które ma szereg odmian, jest typowa forma zużycia zwiqzana z eksploatacja frezów. Jedna z odmian zużycia mechanicznego, często pojawiająca się podczas skrawania materiałów trudnoobrabialnych jest niepożądane zużycie katastroficzne. Unikanie tego rodzaju zużycia poprzez odpowiedni dobór parametrów technologicznych, gatunku węglików spiekanych oraz ich mikrostruktury stanowi podstawowa informację o niezawodności narzędzia. W pracy przedstawiono wyniki badań doświadczalnych wpływu wielkości ziaren węglików spiekanych we frezach walcowo-czołowych na trwatość ostrza i topografie powierzchni po procesie frezowania rowków w stopie tytanu Ti6Al4V. Wskaźniki zużycia wyznaczono w oparciu o norme PN-ISO 8688: 1996. Wykazano, że frezy o strukturze ultradrobnoziarnistej sq najbardziej odporne na wykruszenia, a powierzchnia po obróbce charakteryzuje się najmniejsza chropowatościa. Najmniejsza trwałościa charakteryzują się frezy o strukturze gruboziarnistej.
\end{abstract}

Stowa kluczowe: stopy tytanu, frezowanie, zużycie, chropowatość powierzchni.

\section{Introduction}

The operation of cutting tools renders their teeth (or bits) gradually worn out, leading to the loss of cutting performance. The service life of tool teeth has an impact on the manufacturing cost of items due to the pricing of worn out cutting tools, the costs of reconditioning worn out cutting tools, and the costs of processing machine standstill required for retooling.

The main factors of tool tooth service life include the machined material, the tooth material, the wear protection coating type, the machining parameters and the cooling lubricant type $[5,8,13,17]$. The tool tooth materials should be chosen with cost effectiveness and technical (processing) considerations $[18,20]$. Tool tooth wear is damaging to machining processes. If the machining path length is increased (and hence the tooth wear grows), the cutting force and amplitude value must also increase [10]. As the tool tooth wear grows, the temperature within the machining zone is increased to a point that may result in hazards to machining safety $[11,21]$. This relationship also increased the internal tensile stresses within the superficial layer of the workpiece [4].

Titanium alloys are materials the machining of which results in fast wearing of tool teeth $[1,2,9]$. The high tool wear rates are caused by the properties of titanium alloys: extremely low thermal conductivity, relatively high machining resistance, and the affinity for forming deposits and friction adhesion due to high superficial energy levels. The investigation into the process of wearing TiAlN coated $\mathrm{SC}$ tooth bits (tool plates) with a counter-sample made of Ti6Al4V demonstrated that the tool wear is caused by adhesive reactions that are combined with high friction reaction of the titanium alloy. The tool wear also increases with feed force and slip velocity [6]. The tool tooth wear process was also studied during milling a Ti-6242S alloy workpiece with SC milling cutters with and without a TiN, TiC or TiCN coating [1].

When machining a titanium alloy, the highest force in the process is the thrust force that negatively affects the geometric accuracy of the workpiece. When compared to cutting force and feed force values, the

(*) Tekst artykułu w polskiej wersji językowej dostępny w elektronicznym wydaniu kwartalnika na stronie www.ein.org.pl 
thrust force shows a higher increase with the increase of the tool wear [9]. Hence, given a relatively small Young modulus values of titanium alloy, an increase of a tool tooth wear is expected to result in an increasing scope and number of shape errors in workpieces.

A major quality indicator of machined workpieces is surface roughness. This parameter affects the performance of machine parts, including their fatigue strength, tribological wear resistance and corrosion resistance. The main factors affecting machined surface roughness include feed, corner radius, contact angle, and workpiece material. The paper [7] demonstrated that the machined surface roughness of the TA15 alloy also depends on the tool tooth material and the tool tooth wear. The paper [19] shows the findings of an investigation of the impact of machining parameters on the quality of the Ti6Al4V and pure titanium machined surfaces. Optimal milling technical parameters were selected in the aspect of obtaining minimal roughness and accurateness. During turning spherical surface, due to lower milling speed, higher roughness values were obtained nears the axis of the machined object.

The surface roughness formed by machining may affect the downstream operations on workpieces. It was found that the effectiveness of peening, an operation frequently applied after machining and evaluated with the restitution coefficient values, depends on machined surface roughness [3]. The research completed as discussed in [14] proved that the surface roughness of workpieces milled with various feed rates affects the strength of adhesive bonds.

In the recent years, there has been a trend for manufacturing integrated components (especially in the aerospace industry), which are functional substitutes for assemblies comprising anywhere between dozens or hundreds of individual parts. An integrated component usually features a very complex design and its manufacturing usually involves subtraction of several dozen percent of the intermediate or blank material. The thin wall sections typical of integrated components make their manufacturability difficult due to a high risk of machining instability. The removal of successive solid material layers changes the workpiece geometry and the stability factor $[12,15]$.

Most papers concerning titanium alloy milling focus on machining of planes. The machine cutting of planes is far easier than slot milling, and slots are frequent features of integrated components. Slotting of a solid material includes a cutting width equal to the slot width, and the cutter contact angle is $180^{\circ}$. This inhibits effective heat dissipation from the machining zone and causes the cutting tool to heat more, resulting in an accelerated wear of its teeth. High feed force values deform shank-mounted milling cutters, which may increase machined surface roughness or tool failure wear if the conditions become extremely unfavourable. Special supports can be used to counter these effects - especially when the cutter reach to diameter ratio is very large, as in deep and narrow slot milling [16].

The shape of milled slots usually requires solid (monolithic) milling cutters, which are most often made of sintered carbide (SC). The properties of SC depend on the chemical composition and the grain size. The reference literature research suggests that the service life testing of milling cutter teeth used for slotting of titanium alloys have not included the criterion of SC grain size so far. The objective of the testing contemplated herein was to determine the impact of the grain size in solid SC milling cutters on the tooth service life and machined surface roughness during slotting of workpieces made of Ti6Al4V.

\section{Research methodology}

The experiment covered herein was carried out on test samples made of annealed Ti6Al4V, a material which is widely used aerospace, automotive, medical and other industries, thanks to its proper- ties. The Ti6Al4V chemical composition and physical properties are listed in Table 1.

The experimental test involved slot milling the test specimen with a cutting width equal to the cutter diameter, i.e. $a_{e}=D$. These machining conditions usually put a relatively high strain on the tool. An alternative application consists in a milling cutter the diameter of which is less than the slot width and various machining strategies: equidistant, trochoidal, etc. However, given a known slot depth, the tool rigidity is reduced inversely proportional to the $\mathrm{L} / \mathrm{D}$ ratio (the tool reach to diameter), and the machining time is extended. Fig. 1 shows an example of the test sample and its model with marked dimensions.
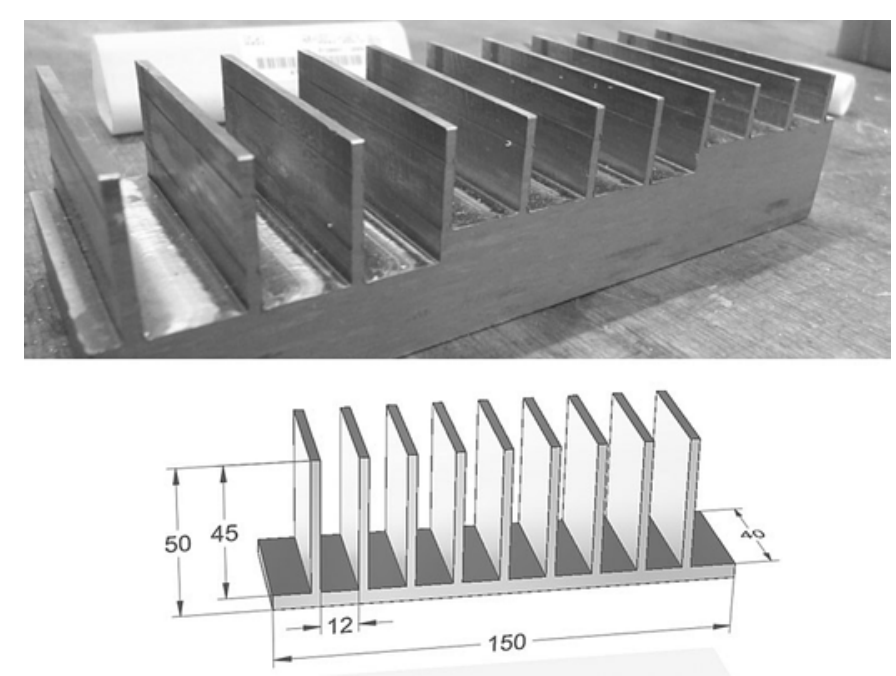

Fig. 1. Test sample form and dimensions

The experimental tests were done on an Avia VMC-800HS machining centre. This machine was equipped with a Heidenhain controller and dedicated to HSM (high-speed machining) with a $25 \mathrm{~kW}$ spindle and the maximum speed of 24,000 rpm.

The tests were carried out on SC milling cutters made with $\mathrm{D}=12$ $\mathrm{mm}$. 4-tooth cutters were used with a geometry adjusted to poorly machinable materials. The variable of these tests was the $\mathrm{SC}$ grain size within a cobalt binder matrix. The first test group of milling cutters had an ultra fine grain SC substrate. The second test group included milling cutters with a fine grain SC substrate. The third test group included milling cutters with a coarse grain SC substrate. For the studies tools of ultra fine-grained and coarse-grained structure were used, four pieces of each, as well as six pieces of tools of fine-grained structure. Table 2 shows the photographic images of the microstructure of the cutters from the test groups at 1000x of magnification.

The SC grain size largely affects the cutter wear rate, especially if the wear conditions are dynamic (variable). Another factor of tool material strength is the cobalt percentage share in the binder phase which may vary from several do ca. $30 \%$ in cutting tools. The test tools were mounted in tool holders at a constant tool reach length.

Given the dynamics of machining processes, the tool wear is a process complex in nature and may include a combination of any of the following: mechanical wear, adhesive wear, diffusive wear, thermal wear or chemical wear. The experimental tests discussed herein 
Table 2. Microstructures of specific cutter test groups (magnification: 1000x)

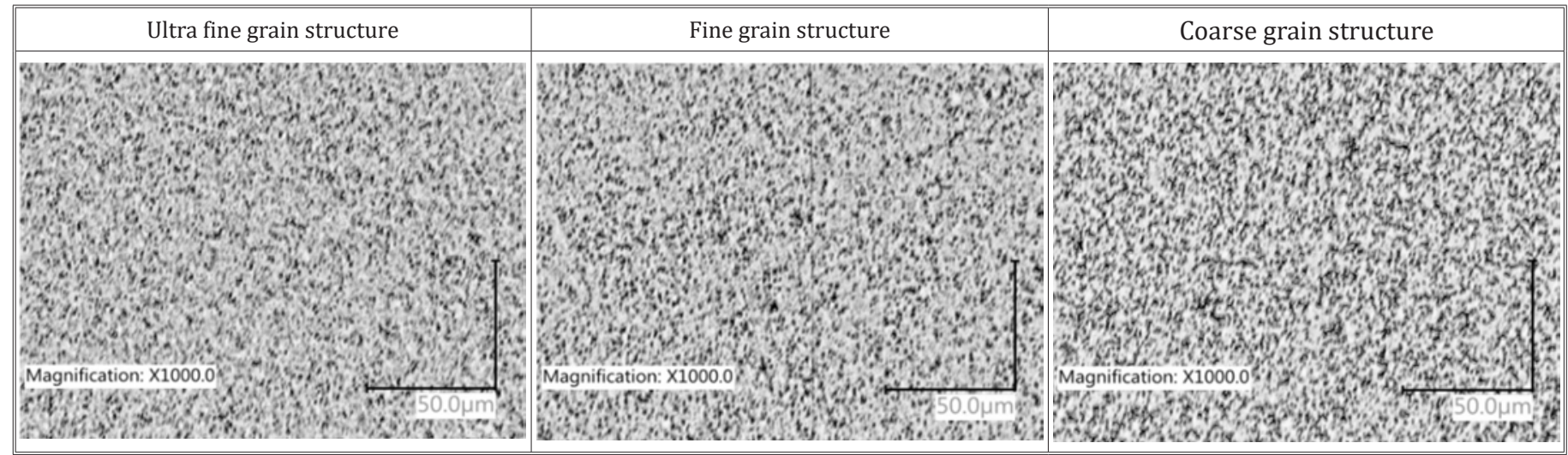

focused on mechanical wear, which can be divided into the subcategories of abrasive wear and strength (emergency or fatigue) wear. Several tool tooth wear criteria can be applied: geometric, processing, physical and economic. Geometric criteria are applied to measure the wear that is directly related to the condition of the cutting tool tooth. The tool tooth wear indicators were determined in compliance with PN-ISO 8688:1996. The test measurements included tool service life, cutting path, and slot bottom surface roughness. The tooth tool wear indicators were measured under a Keyence VHX 5000 digital imaging microscope.

The experimental tests had constant machining values. The cutting speed was $v_{c}=30 \mathrm{~m} / \mathrm{min}$ and the feed per tooth was $f_{z}=0.14 \mathrm{~mm} /$ tooth. The cutting depth selected for slot milling was $a_{p}=2 \mathrm{~mm}$ at a cutting width of $a_{e}=12 \mathrm{~mm}$, equal to the diameter of the test milling cutters. The parameter values were assumed from the range of those recommended by manufacturers of tools used during the experiment.

The surface roughness was measured with a HOMMEL-ETAMIC T8000 RC120 machine for roughness, 3D topography and contour mapping.

To analyse the tool wear and its effect on the machined surface quality, the milling process was interrupted at predetermined time steps to measure the tool wear and surface roughness. The time steps were: $0.1 ; 0.5 ; 1 ; 3 ; 5 ; 8 ; 11 ; 15 \mathrm{~min}$.

\section{Test results}

Of all the mechanical wear forms defined in PN-ISO 8688:1996, three wear types were witnessed during the experimental tests: localized flank wear, $V B 3$, localized chipping, $\mathrm{CH} 3$, and catastrophic failure, $C F$. Table 3 shows a graphical representation of the discovered wear types with actual images thereof.

Fig. 2 shows a comparative view of a milling cutter after the machining time $\mathrm{t}=15 \mathrm{~min}$ (Fig. 2a) and a new milling cutter (Fig. 2b). This milling cutter is made of fine grain SC.

Several wear types usually occurred on the studied tool teeth. A tool tooth initially revealed localized flank wear VB3. Small defects of the materials change the machining conditions and the localized stress concentration. A consequence of these factors was the emergence of localized chipping $\mathrm{CH} 3$. A chipping area may thus form a "new" cutting edge the geometry of which was random and undefined (this phenomenon occurs in abrasive machining and it is caused by grain fissility). Once the critical wear $\mathrm{VB} 3+\mathrm{CH} 3$ is reached as determined for a given tool, the tool wear results in failure wear CF. These effects cannot always be witnessed, which is due to the dynamic nature of machining. A failure wear of one tooth without interruption of the rotational movement of a milling cutter usually results in fracture of all remaining teeth. If a CNC machine tool has no systems to immediately interrupt the machining process upon a tool failure, the feed

Table 3. Found wear types

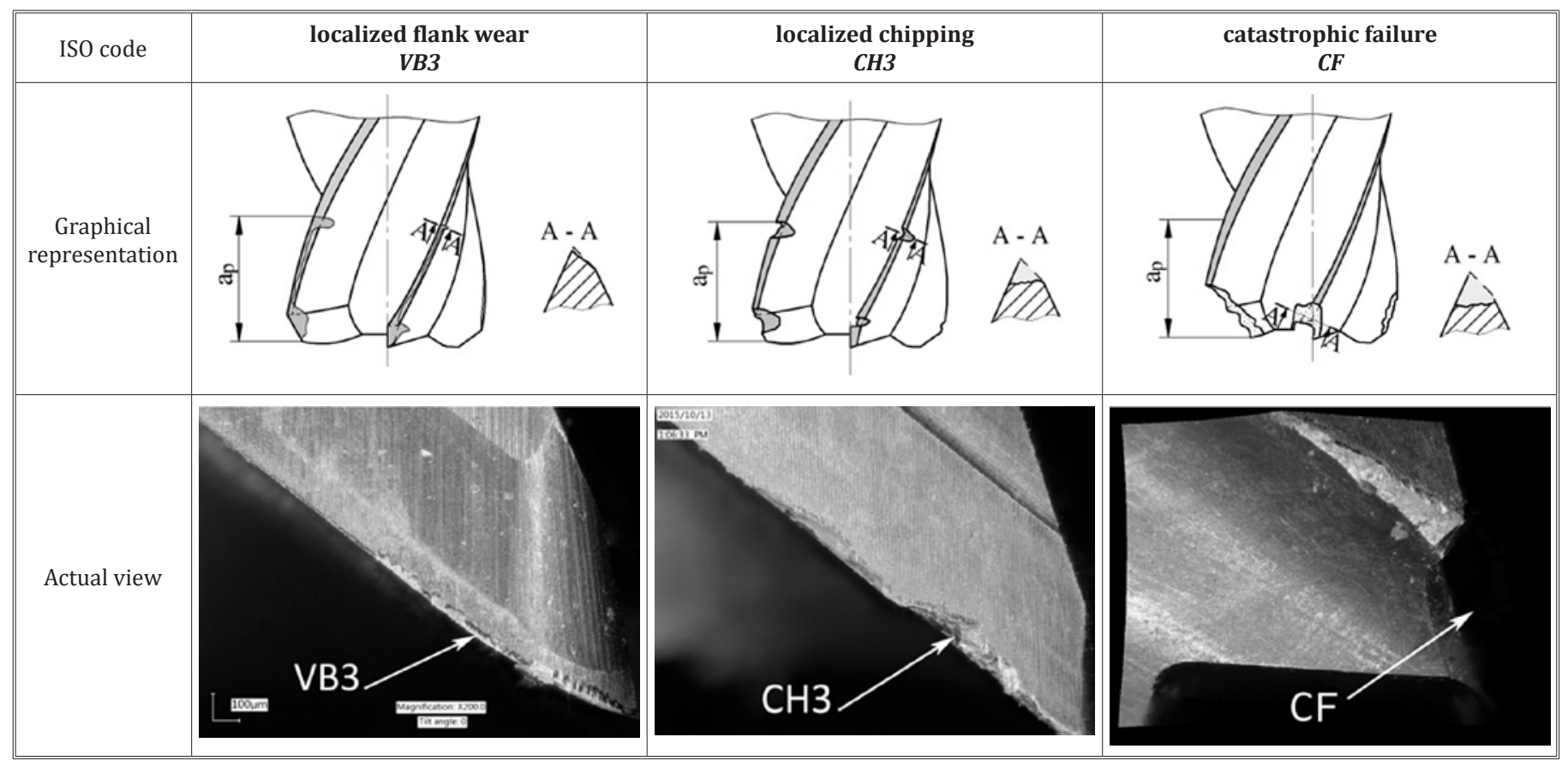


a)

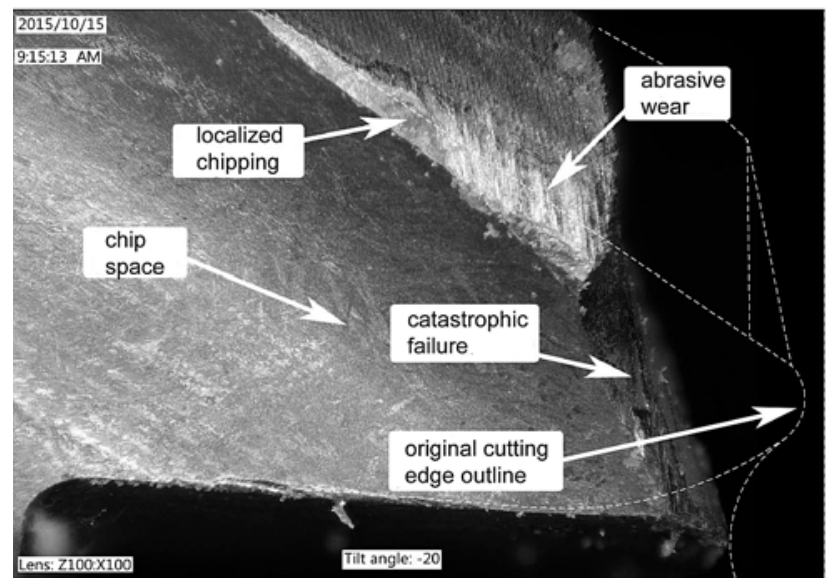

Fig. 2. Tool tooth condition: (a) after machining $t=15 \mathrm{~min}$, (b) new
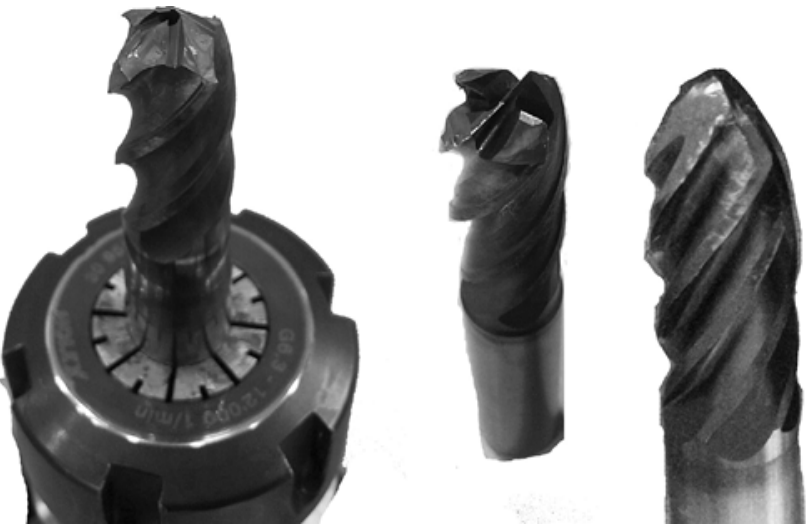

Fig. 3. Examples of cutters subject to failure

of the workpiece material into a tool with lost teeth causes collision conditions which result in breaking away the entire tool at its held base or over the machined surface plane. An overview of failed cutters is shown in Fig. 3.

Table 4. Comparison of new tool teeth to worn tool teeth
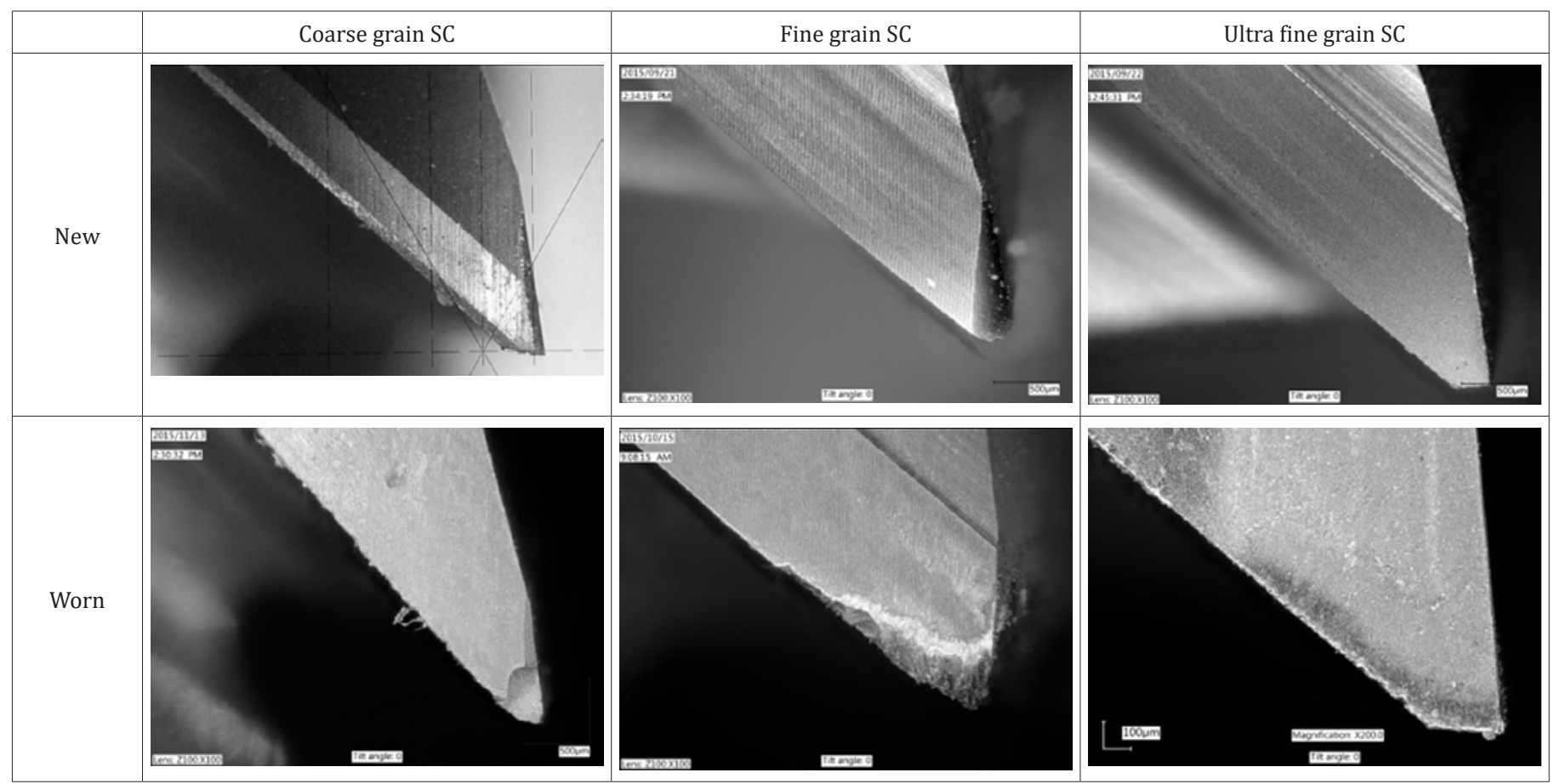

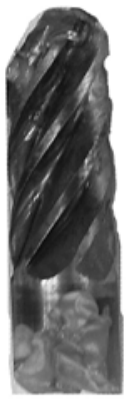

Table 4 shows selected photographs of new and worn tool teeth.

Fig. 4 shows a chart of the localized flank wear $V B 3$ as a function of the machining time. Coarse-grain SC teeth suffered from chipping at the initial stages of the experimental tests; hence, the tool tooth wear measurement results were followed only to the machining time $t=0.5$ min. The least worn tool teeth had a fine-grain $\mathrm{SC}$ with a mean wear value $V B 3=0.17 \mathrm{~mm}$ after the machining time $t=15 \mathrm{~min}$.

An analysis of the localized flank wear $V B 3$ did not provide a full insight into the tool tooth service life due to the concurrent presence of other wear types. Fig. 5 shows the percentage of the milling cutters which displayed the chipping wear CH3.

$12.5 \%$ of all ultra fine SC milling cutters were worn out within the last time interval, i.e. $t=12$ to $15 \mathrm{~min}$. The population of $87.5 \%$ suffered only from localized flank wear $V B 3$.

The largest share of localized chipping of fine grain SC milling cutters was occurred at the first minutes of machining. Past the machining time $t=15 \mathrm{~min}$, the total percentage of milling cutters with CH3 was $100 \%$.

All coarse grain SC milling cutter teeth revealed localized chipping at $t=0$ to $3 \mathrm{~min}$. 
A localized chipping $\mathrm{CH} 3$ is not tantamount to a complete loss of cutting performance of a tool. However, it is often a prelude to a very quick catastrophic failure $C F$.

Fig. 6 shows the distribution of the catastrophic failure $C F$ percentage ration in milling cutters of various SC grain sizes. The ultra fine grain $\mathrm{SC}$ cutters did not reveal $\mathrm{CF}$ across the entire machining time. Catastrophic failure $\mathrm{CF}$ is the most undesirable wear type, and a typical problem of automatic $\mathrm{CNC}$ machining that requires retooling, stopping the machining program, constant supervision by process operators, etc.

Approximately $85 \%$ of fine grain SC cutters failed from wear after $\mathrm{t}=15 \mathrm{~min}$

All coarse grain SC cutters failed from wear at $\mathrm{t}=0$ to $3 \mathrm{~min}$.

Fig. 7 shows the effect of the SC microstructure on the surface roughness measured at the defined time points at the sample bottom in the process of slot milling. In any study of machined surface roughness, the so-called running-in phase may be found. When a running-in phase occurs, the surface roughness will either be reduced or reveal no discernible growth as the machine time passes. The running-in phase of the ultra fine grain SC cutters was evident from the machining time $\mathrm{t}=1 \mathrm{~min}$. One possible cause of the running-in phase emergence was that at the initial stage of machining the sharp cutting edge of a tool, the outline of which was formed within the workpiece, generated large micro irregularities; following the period of initial tool wear with an

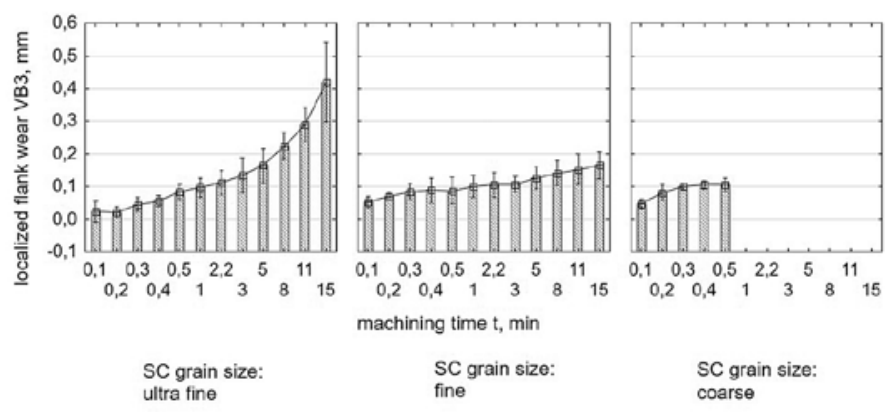

Fig. 4. Localized flank wear vs. machining time
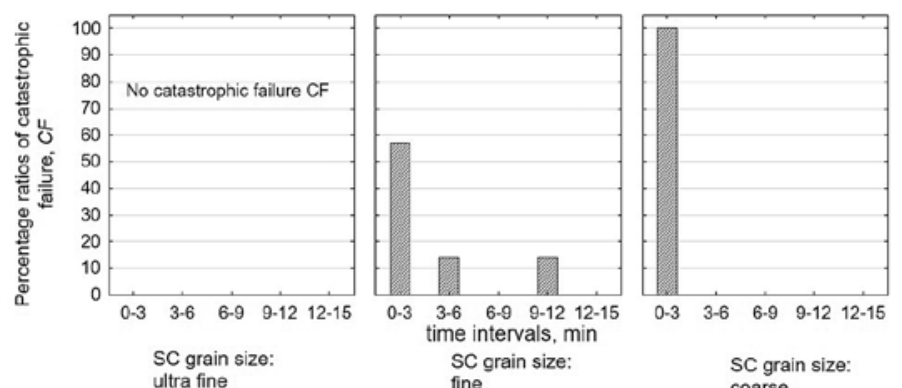

Fig. 6. Percentage ratios of catastrophic failure $C F$ at specific machining time intervals vs. various SC grain sizes a)

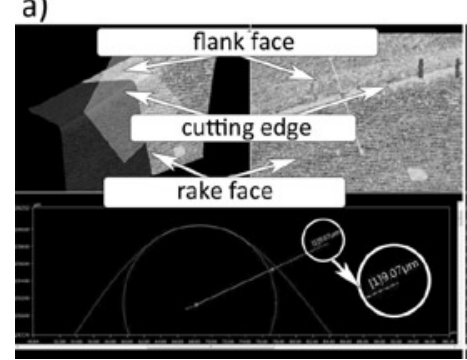

b)

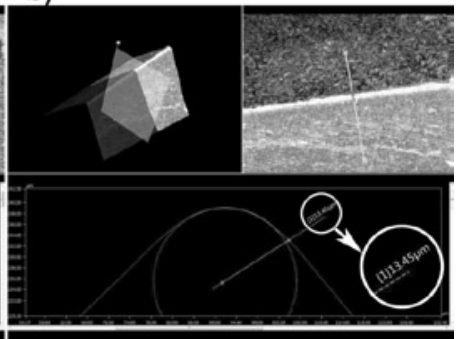

Fig. 8. Comparison between the chamfer radius of the cutting edge of an ultra fine grained SC tool:(a) new cutting edge, (b) after the machining time $t=1 \mathrm{~min}$ increase of the cutting edge chamfer radius, the surface roughness began to fall. Fig. 8 shows a comparison between a chamfer radius of a new cutting edge of an ultra fine grain SC cutter and the chamfer radius of the same cutting edge at the machining time $t=1 \mathrm{~min}$. What was evident after this time was a slow increase in surface roughness during the machining time. This was related to the incrementing values of the tool tooth wear indicators. The fine grain SC cutters revealed a shorter running-in phase. After the machining time $t=0.5 \mathrm{~min}$, a gradual increase in surface roughness was evident, whereas its growth rate was higher than in the machining with ultra fine grain SC tools.

The coarse grain SC tools only revealed a fast increase in surface roughness from the initial machining phase. The measurements were continued up to the time of $C F$. The lowest surface roughness was produced with the ultra fine grain SC tools.

Fig. 9 shows a comparison between the surface topography made with the fine grain $\mathrm{SC}$ tools and ultra fine $\mathrm{SC}$ tools after the machining time $t=8 \mathrm{~min}$.

A characteristic periodic arrangement of micro irregularities is evident that follows the cutting edge within the machined workpiece body, and the surface roughness parameters were much higher than produced with fine grain SC tools.
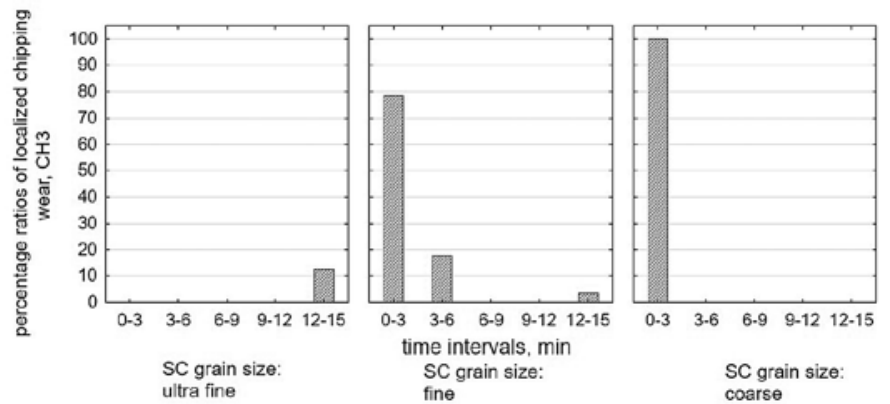

Fig. 5. Percentage ratios of localized chipping wear $\mathrm{CH} 3$ at specific machining time intervals vs. various $S C$ grain sizes
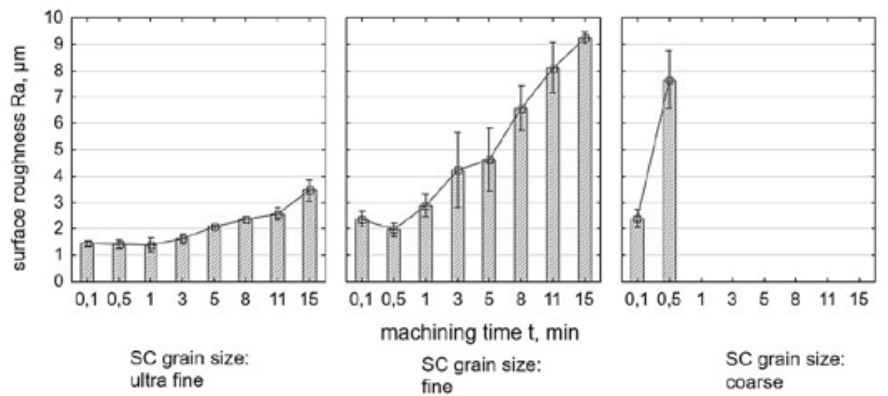

Fig. 7. Impact of the SC structure on surface roughness during slot milling a)

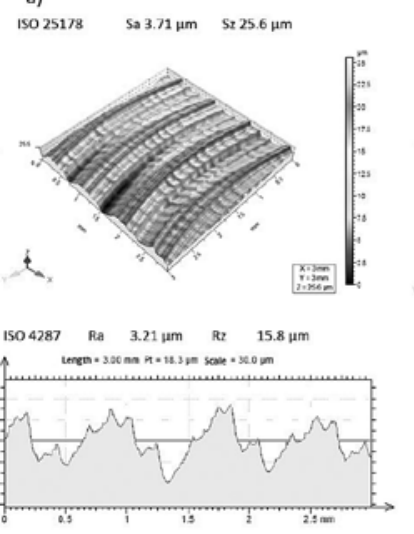

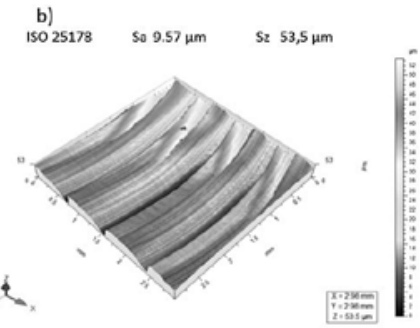

1504287 Rs $6.62 \mu \mathrm{m} \quad \mathrm{Rz} 32.6 \mathrm{\mu m}$

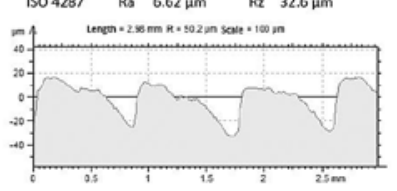

Fig. 9. Comparison of the surface topography at $t=8$ min of machining with: (a) ultra fine grain SC tools, (b) fine grain SC tools 


\section{Summary}

These experimental tests of the effect of various SC grain sizes in tools on the tool service life and machined surface roughness during slot milling, with the established machining technological parameters, of Ti6Al4V alloy workpieces allowed formulating several conclusions.

1. Out of the mechanical wear factors, the most frequent wear types witnessed was localized flank wear $V B 3$, localized chipping $\mathrm{CH} 3$, and catastrophic failure $\mathrm{CF}$.

2. It is advantageous to adjust the $\mathrm{SC}$ grain size to the machined materials as to permit the localized flank wear VB3 only throughout the cutting tool life. If the machining process parameters are known and set, this helps foresee the time to replace the cutting tool.

3. The lowest values of localized flank wear $V B 3$ occurred during machining with fine grain SC tools.

4. Ultra fine SC cutting tools are most resistant to localized chipping and failure wear.

5. No catastrophic failure $C F$ was witnesses for any ultra fine grain $\mathrm{SC}$ cutting tool up to the machining time $\mathrm{t}=15 \mathrm{~min}$. All these tools retained their cutting performance.

6. All coarse grain SC tools suffered failure wear $C F$ in the first phase of the machining process, $\mathrm{t}=0$ to $3 \mathrm{~min}$.

7. The best surface roughness was produced with the ultra fine grain SC tools.
Given the tool tooth life and surface roughness, the best performance quality was produced with the ultra fine grain SC tools. Despite the higher localized flank wear $V B 3$ than in the fine grain SC tools, it is important that all ultra fine grain SC tools retained their cutting performance at the lowest surface roughness of all tested tool groups.

Coarse grain SC tools are not recommended for poorly machinable materials due to the high risk of catastrophic failure $C F$.

On the basis of preliminary research performed milling technological parameters can affect the wear value and percentage of worn mills in particular time intervals, however, the general tendencies connected with the influence of mill structure upon tool life and surface quality will remain on a comparable level.

\section{Acknowledgement}

The test were completed under the industry project INNOLOT (abbreviation: AMpHOra) titled "Testing of additive manufacturing technologies and hybrid processing for the development of innovative aerospace manufacturing" and coordinated by Polskie Zakłady Lotnicze Sp. z o.o. - PZL Mielec, and co-financed by the National Centre for Research and Development (NCBiR) and the European

Union under the European Regional Development Fund for the Operational Programme: Innovative Economy,

OP:IE Priority I, Measure 1.5 Agreement no. INNOLOT /I/6/ $N C B R / 2013$

\section{References}

1. Abdel - Aaal H A, Nouari M, Mansori M El. Influence of thermal conductivity on wear when machining titanium alloys. Tribology International 2009; 42: 359-372, https://doi.org/10.1016/j.triboint.2008.07.005.

2. Bach P, Trmal G, Zeman P, Vana J, Maly J. High performance titanium milling at low cutting speed. Procedia CIRP 2012; 1: 226-231, https:// doi.org/10.1016/j.procir.2012.04.040.

3. Bławucki S, Zaleski K. The effect of the aluminium alloy surface roughness on the restitution coefficient. Advances in Science and Technology Research Journal 2015; 9(27): 66-71, https://doi.org/10.12913/22998624/59086.

4. Chen L, El-Wardany T I, Harris W C. Modelling of the effects of flank wear land and chip formation on residual stresses. Annals of the CIRP 2004; 53(1): 95-98, https://doi.org/10.1016/S0007-8506(07)60653-2.

5. Ezugwu E O, Wang Z M. Titanium alloys and their machinability - a review. Journal of Materials Processing Technology 1997; 68: 262-274, https://doi.org/10.1016/S0924-0136(96)00030-1.

6. Grzesik W, Małecka J, Zalisz Z, Żak K, Niesłony P. Investigation of friction and wear mechanisms of TiAlN coated carbide against Ti6Al4V titanium alloy using pin - on discs tribometer. Archive of Mechanical Engineering 2016; 63(1): 113-127, https://doi.org/10.1515/meceng2016-0006.

7. Honghua S U, Peng L I U, Yucan F U, Jiuhua X U. Tool life and surface integrity in high - speed milling of titanium alloy TA15 with PCD/ PCBN tools. Chinese Journal of Aeronautics 2012; 25: 784-790, https://doi.org/10.1016/S1000-9361(11)60445-7.

8. Krolczyk G M, Nieslony P, Legutko S. Determination of tool life and research wear during duplex stainless turning. Archives of Civil and Mechanical Engineering 2015; 15(2): 347-354, https://doi.org/10.1016/j.acme.2014.05.001.

9. Krupa K, Sieniawski J, Laskowski P. Zużycie narzędzi skrawających podczas toczenia stopu Ti-6Al-2Sn-4Zr-6Mo. Mechanik 2010; 10: 654-661.

10. Kuczmaszewski J, Pieśko P. Wear of milling cutters resulting from high silicon aluminium alloy cast AlSi21CuNi machining. Eksploatacja i Niezawodnosc - Maintenance and Reliability 2014; 16(1): 37-40.

11. Kuczmaszewski J, Zagórski I, Dziubinska A. Investigation of ignition temperature, time to ignition and chip morphology after the high-speed dry milling of magnesium alloys. Aircraft Engineering and Aerospace Technology: An International Journal 2016; 88(3): 389-396, https:// doi.org/10.1108/AEAT-02-2015-0040.

12. Kuczmaszewski J, Zaleski K, Ed. Obróbka skrawaniem stopów aluminium i magnezu. Lublin: Politechnika Lubelska, 2015.

13. Nabhani F. Machining of aerospace titanium alloys. Robotics and Computer Integrated Manufacturing 2001; 17: 99-106, https://oi. org/10.1016/S0736-5845(00)00042-9.

14. Rudawska A, Reszka M, Warda T, Miturska I, Szabelski J, Stancekova D, Skoczylas A. Milling as a method of surface pretreatment of steel for adhesive bonding. Journal of Adhesion Science and Technology 2016; 30(23): 2619-2636, https://doi. org/10.1080/01694243.2016.1191585.

15. Rusinek R, Zaleski K. Dynamics of thin - walled element milling expressed by recurrence analysis. Meccanica 2016; 51(6): 1275-1286, https://doi.org/10.1007/s11012-015-0293-y.

16. Shamato E, Saito A. A novel deep groove machining method utilizing variable - pitch end mill with feed - directional thin support. Precision Engineering 2016; 43: 277-284, https://doi.org/10.1016/j.precisioneng.2015.08.006.

17. Su Y, He N, Li L. An experimental investigation of effects of cooling/lubrication conditions on tool wear in high - speed end milling of Ti6Al-4V. Wear 2006; 261: 760-766, https://doi.org/10.1016/j.wear.2006.01.013. 
18. Twardowski P, Legutko S, Krolczyk G M, Hloch S. Investigation of wear and tool life of coated carbide and cubic boron nitride cutting tools in high speed milling. Advances in Mechanical Engineering 2015; 7(6): 1-9, https://doi.org/10.1177/1687814015590216.

19. Zębala W, Gawlik J, Matras A, Struzikiewicz G, Ślusarczyk Ł. Research of surface finish during titanium alloy turning. Key Engineering Materials 2014; 581: 409-414, https://doi.org/10.4028/www.scientific.net/KEM.581.409.

20. Zareena A R, Rahman M, Wong Y S. Binderless CBN tools, a breakthrough for machining titanium alloys. Journal of Manufacturing Science and Engineering 2005; 127(2): 277-279, https://doi.org/10.1115/1.1852570.

21. Zoya Z A, Krishnamurthy R. The performance of CBN tools in the machining of titanium alloys. Journalof Materials Processing Technology 2000; 100: 80-86, https://doi.org/10.1016/S0924-0136(99)00464-1.

\author{
Józef KUCZMASZEWSKI \\ Kazimierz ZALESKI \\ Jakub MATUSZAK \\ Tomasz PAŁKA \\ Department of Production Engineering \\ Mechanical Faculty \\ Lublin University of Technology \\ ul. Nadbystrzycka, 20-618 Lublin, Poland
}

\section{Janusz MĄDRY}

Polskie Zakłady Lotnicze Sp. z o.o. - PZL Mielec

E-mails: j.kuczmaszewski@pollub.pl,k.zaleski@pollub.pl, j.matuszak@pollub.pl,t.palka@pollub.pl, janusz.madry@lmco.com 